\title{
REVIEW
}

\section{Current challenges in the management of sepsis in ICUs in resource-poor settings and suggestions for the future}

\author{
Marcus J. Schultz ${ }^{1,2^{*}}$, Martin W. Dunser ${ }^{3}$, Arjen M. Dondorp" ${ }^{1,2}$, Neill K. J. Adhikari ${ }^{4}$, Shivakumar lyer ${ }^{5}$, \\ Arthur Kwizera ${ }^{6}$, Yoel Lubell ${ }^{2}$, Alfred Papali ${ }^{7}$, Luigi Pisani ${ }^{1,2}$, Beth D. Riviello ${ }^{8}$, Derek C. Angus ${ }^{9}$, \\ Luciano C. Azevedo ${ }^{10}$, Tim Baker ${ }^{11}$, Janet V. Diaz ${ }^{12}$, Emir Festic ${ }^{13}$, Rashan Haniffa', Randeep Jawa ${ }^{14}$, \\ Shevin T. Jacob ${ }^{15}$, Niranjan Kissoon ${ }^{16}$, Rakesh Lodha ${ }^{17}$, Ignacio Martin-Loeches ${ }^{18}$, Ganbold Lundeg ${ }^{19}$, \\ David Misango ${ }^{20}$, Mervyn Mer ${ }^{21}$, Sanjib Mohanty ${ }^{22}$, Srinivas Murthy ${ }^{16}$, Ndidiamaka Musa ${ }^{23}$, Jane Nakibuuka ${ }^{6}$, \\ Ary Serpa Neto ${ }^{2,24}$, Mai Nguyen Thi Hoang ${ }^{25}$, Binh Nguyen Thien ${ }^{26}$, Rajyabardhan Pattnaik ${ }^{22}$, Jason Phua ${ }^{27}$, \\ Jacobus Preller ${ }^{28}$, Pedro Povoa ${ }^{29}$, Suchitra Ranjit ${ }^{30}$, Daniel Talmor ${ }^{8}$, Jonarthan Thevanayagam ${ }^{31}$, \\ C. Louise Thwaites ${ }^{32}$ and For the Global Intensive Care Working Group of the European Society of Intensive \\ Care Medicine
}

\begin{abstract}
Background: Sepsis is a major reason for intensive care unit (ICU) admission, also in resource-poor settings. ICUs in low- and middle-income countries (LMICS) face many challenges that could affect patient outcome.

Aim: To describe differences between resource-poor and resource-rich settings regarding the epidemiology, pathophysiology, economics and research aspects of sepsis. We restricted this manuscript to the ICU setting even knowing that many sepsis patients in LMICs are treated outside an ICU.

Findings: Although many bacterial pathogens causing sepsis in LMICs are similar to those in high-income countries, resistance patterns to antimicrobial drugs can be very different; in addition, causes of sepsis in LMICs often include tropical diseases in which direct damaging effects of pathogens and their products can sometimes be more important than the response of the host. There are substantial and persisting differences in ICU capacities around the world; not surprisingly the lowest capacities are found in LMICs, but with important heterogeneity within individual LMICS. Although many aspects of sepsis management developed in rich countries are applicable in LMICs, implementation requires strong consideration of cost implications and the important differences in resources.
\end{abstract}

Conclusions: Addressing both disease-specific and setting-specific factors is important to improve performance of ICUs in LMICs. Although critical care for severe sepsis is likely cost-effective in LMIC setting, more detailed evaluation at both at a macro- and micro-economy level is necessary. Sepsis management in resource-limited settings is a largely unexplored frontier with important opportunities for research, training, and other initiatives for improvement.

\footnotetext{
*Correspondence: marcus.j.schultz@gmail.com

${ }^{2}$ Department of Intensive Care, Academic Medical Center and University of Amsterdam, Meibergdreef 9, 1105 AZ Amsterdam, The Netherlands Full author information is available at the end of the article

Take-home message: ICUs in low- and middle-income countries face many challenges that could affect patient outcome. Addressing both disease-specific and setting-specific factors is important to improve performance in these settings. Detailed evaluation at both at a macroand micro-economy level is highly needed.
}

\section{实 Springer}


Keywords: Sepsis management, Critical care, Resource-limited settings

\section{Introduction}

In many low- and middle-income countries (LMICs), the relative importance of curative care to improve health becomes more important with improved public health services, such as sanitation and immunization. This includes care for severe sepsis, a major reason for intensive care unit (ICU) admission in LMICs. These patients will currently often be treated in general wards, but basic intensive care facilities are becoming increasingly available. The scope of the current review is limited to the ICU setting. ICUs in resource-restricted settings have to function with important limitations, including both infrastructure and materials, as well as human resources. It is therefore important to address economic aspects that affect the provision of relatively expensive intensive care in low-income countries. In addition, most LMICs have tropical or subtropical climates, and causes of sepsis will often differ from those in high-income countries (HICs), where most of the sepsis treatment guidelines have been developed. Because of the different setting and the different causes of sepsis, existing guidelines therefore need to be interpreted carefully. Although there is a broad research agenda in place, the current situation has scarcely been addressed. Finally, expansion of settingadapted training will be important to improve ICU performance in LMICs.

This review, written by a group of physicians from resource-poor and -rich ICUs in LMICs and HICs, respectively, who were involved in the development of a series of sets of recommendations for sepsis management in resource-poor settings that were recently published in Intensive Care Medicine [1-4], compares the estimated burden, pathogens and pathophysiology of sepsis between resource-poor and resource-rich settings. The availability of critical care and guidelines and the costs of critical care in LMICs are compared to those in HICs. Suggestions for future directions are provided.

\section{Burden and causes of sepsis and its management Disease burden}

While detailed information has been reported on the epidemiology and outcome of sepsis in HICs [5, 6], systematically collected epidemiological data from LMICs are limited $[7,8]$, even though about $80 \%$ of the global mortality caused by infections occur in these countries [9]. At present, the epidemiology of sepsis in LMICs can only be loosely estimated from the epidemiology of acute infectious diseases with a potential to cause sepsis captured in the Global Burden of Disease database
[10-12]. This database reported important regional differences in the epidemiology of acute infectious diseases (Fig. 1). For example, while the majority of acute infections in resource-limited settings are acquired in the community [9], the incidence of nosocomial infections, such as catheter-related bloodstream infections or ventilator-associated pneumonia, are several fold higher in LMICs than in HICs such as the USA [13]. Similarly, although little data on sepsis mortality in LMICs have been published to date, data which are available suggest that sepsis-related mortality varies greatly among regions and countries according to their income level. While the number of deaths due to sepsis have been steadily decreasing in high-income countries over the last decades to $30-40 \%[5,6]$, mortality rates of up to $80 \%$ continue to be reported from resource-poor regions of the world [14-17].

\section{Causative pathogens and pathogenesis}

Although many bacterial pathogens causing sepsis in LMICs are similar to those in HICs, resistance patterns to antimicrobial drugs can be very different. It has been suggested that the high prevalence of multi-drug resistant bacteria, including methicillin-resistant Staphylococcus aureus, extended-spectrum beta-lactamases-producing bacteria, carbapenamase-producing Enterobacteriaceae and Mycobacterium tuberculosis, contribute to the excess deaths observed in LMICs caused by invasive infections with these bacteria, particularly among infants $[13,18]$. The five countries with the highest burden of death in children under 5 years (China, Nigeria Pakistan, India and the Democratic Republic of Congo) also have the highest rate of neonatal deaths from antimicrobial resistance [19]. The challenges encountered in managing antimicrobial resistance and its implications for the treatment of sepsis in LMICs have very recently been described by Thwaites et al. [4].

Whereas the majority of severe sepsis in HICs is caused by bacterial infections, in LMICs, many of which are located in the tropics, causes of severe sepsis also include acute non-bacterial diseases, including protozoal diseases, such as malaria, and viral diseases, such as measles, dengue or viral hemorrhagic fevers. The international literature mainly focuses on sepsis caused by invasive bacterial infections and the associated systemic inflammatory response [20,21]. Therefore, non-bacterial causes are understudied, and the acquired knowledge on the pathophysiology and treatment of sepsis may not be generalizable to these other causes of sepsis [22]. 


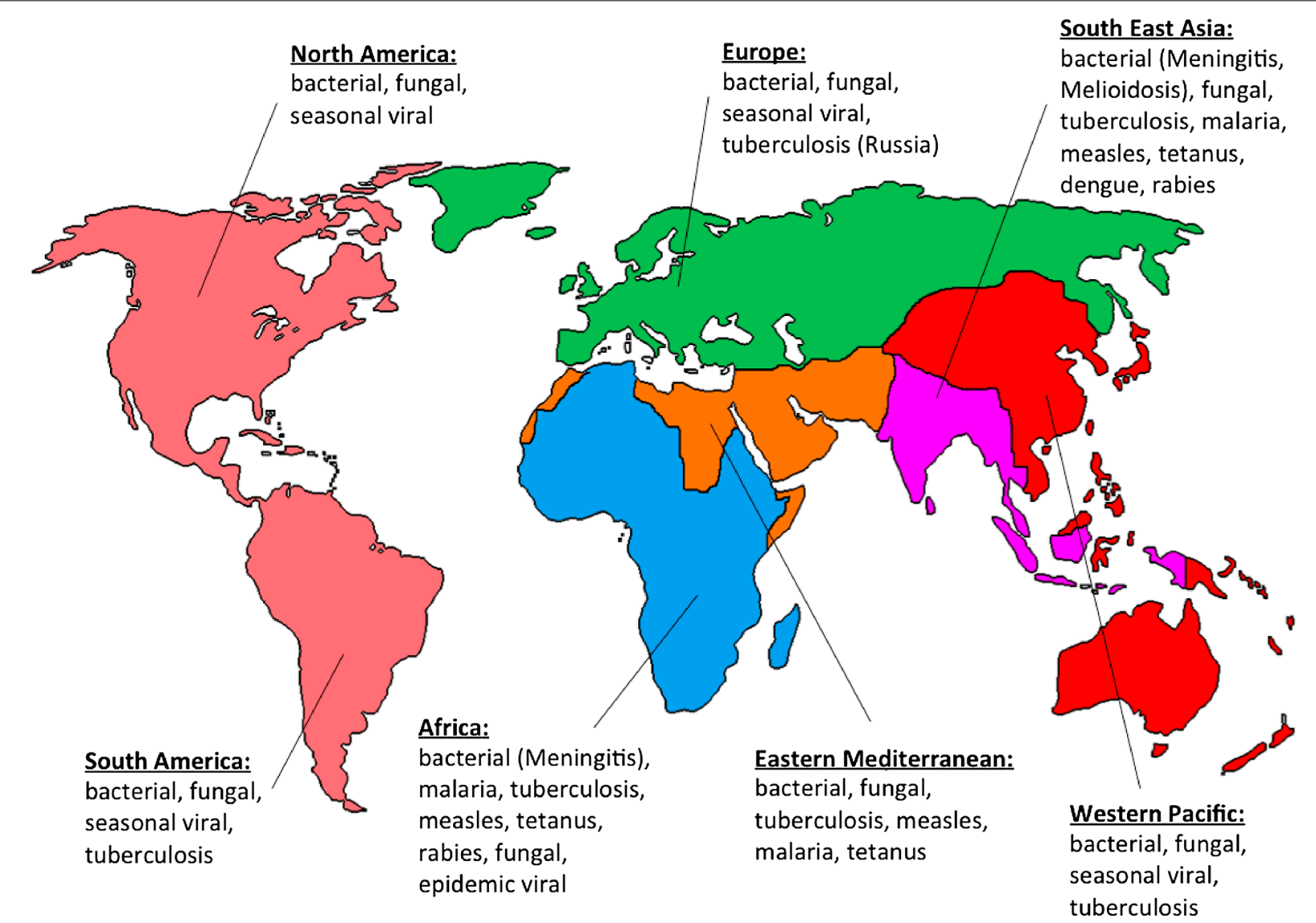

Fig. 1 Most relevant infectious diseases as reported by the Global Burden of Diseases study stratified by the six World Health Organization regions. From Global Burden of Disease Study 2013 [10] and Collaborators GBD 2015 Mortality and Causes of Death Collaborators [11], with permission

Previous sepsis definitions strongly emphasized the 'dysregulated response of the host's immune system' as the key element of the pathogenesis of sepsis [23, 24]. Although this concept is generally correct, it ignores the potential direct damaging effects of certain pathogens or pathogen products, which can in particular play a role in tropical diseases. For example, in severe falciparum malaria, a blocked microcirculation resulting from the sequestered infected red blood cell biomass is a direct cause of vital organ failure [25], and in dengue shock syndrome virus proteins are thought to damage the glycocalyx lining the endothelium directly $[26,27]$. Intervening in these pathophysiological pathways will obviously require therapeutic approaches different from those used in bacterial sepsis.

\section{Poor availability of critical care}

There is persisting substantial heterogeneity in ICU capacity around the world. In the HICs of Europe and Northern America, capacity is between 5 and 30 beds per $1,00,000$ inhabitants. The scarce data available show that capacity is much lower-albeit quite variable-in LMICs [28]. Take Asia for example: reported ICU capacity is only 0.3 beds per 1,00,000 inhabitants in Bangladesh, 2.4 per 1,00,000 inhabitants in Malaysia, 2.5 per 1,00,000 inhabitants in Sri Lanka and 3.9 per 1,00,000 inhabitants in China [29] while it is 11.7 adult and pediatric ICU beds per 1,00,000 inhabitants in Mongolia [30]. Studies from several countries in Sub-Saharan Africa have reported as few as $0.1-0.2$ ICU beds per 1,00,000 inhabitants [31, 32]. With the exception of Mongolia [30] and Latin American countries [33], almost no data on the availability of dedicated pediatric ICU capacities have been published for resource-limited settings [34].

We tend to look at LMICs as if they are 'uniform', but this is a too simplistic-if not naive-approach. Within and between LMICs, there is important heterogeneity in terms of the availability of intensive care, resourcing of ICUs, quality of services and case-mix [35]. The rapidly expanding urban population in many LMICs will provide a challenge for current urban ICU capacity because of the associated increase in case load [36]. 
Another problem in reporting ICU capacity is the lack of a commonly agreed definition of an ICU or an ICU bed $[37,38]$. The spectrum of how ICUs are staffed and equipped differs vastly between countries and regions. Table 1 summarizes published evidence and the personal experiences of the authors in an attempt to categorize different ICU structures worldwide. As surveys from various countries suggest, the availability of ICU-related material resources directly correlates with the countries' income level and healthcare spending [7, 31, 32, 39-43]. The shortage of medical professionals specifically trained in the care of acutely and critically ill patients is another widespread and serious challenge for ICU services in many LMICs [31, 32, 39-42]. A notable exception to this is well-staffed and equipped ICUs in private healthcare facilities. Such services can typically be found in some Shigh- and middle-income countries, but these usually remain only accessible for those who can afford this.

The increasing but still low ICU capacity in poorer regions of the world [44] implies that access to ICU services for critically ill patients is usually severely limited. This results in frequent triage decisions [32], which likely increases mortality from preventable disease [45]. Even though costs of care in ICUs of resource-limited settings are only a fraction of those in ICUs of high-income countries [46], expenses for ICU care are usually to a large extent covered by the patient's family and relatives in LMICs. Unwanted consequences can be denial or refusal of ICU admission of poor patients, but also the premature withdrawal of life-saving interventions [47, 48]. In other instances, costs of care for a critically ill patient, who may eventually die, can exceed the limited budget of many families, leaving them with high debts or even causing private bankruptcy.

\section{Incomplete and unadjusted guidelines}

The principle of 'evidence-based medicine' is equally important in resource-limited as in resource-rich settings. Development of local evidence is important, since case-mix and causes of sepsis, but also available infrastructure and facilities are essentially different from those in Western countries. Resource-limited ICUs are frequently limited in terms of availability of equipment, laboratory support and skilled physician and nursing staff. As a result, recommendations on sepsis management in resource-poor settings, such as those developed by the 'Global Intensive Care Working Group' of the European Society of Intensive Care Medicine (ESICM) [49] differ in several aspects from the Surviving Sepsis Campaign guidelines, which were developed in high-income settings [50]. Obvious examples include targeting strict blood glucose levels with insulin, a strategy which can be safe with frequent and reliable blood glucose monitoring but dangerous when the effects of insulin titrations are determined infrequently or not at all. Other modifications in recommendations for sepsis management could result from the differences in availability of and indications for fluids in sepsis patients between resource-rich and resource-poor settings, but also the cause of sepsis (see also Table 2). Recently, our group of physicians from resource-poor and resource-rich countries took the initiative to develop sets of recommendations for the management of patients with sepsis in resource-poor ICUs [1-4].

Despite the importance of building 'local' evidence, many aspects of existing guidelines and basic principles of good critical care are universal. Access to adequate information has improved massively in this cyber age, and several courses (such as the BASIC for Developing

Table 1 Proposal for a categorization of intensive care units

\begin{tabular}{|c|c|c|c|c|}
\hline Proposed categories & $\begin{array}{l}\text { Category l- } \\
\text { unrestricted }\end{array}$ & $\begin{array}{l}\text { Category II-moderate } \\
\text { restrictions }\end{array}$ & Category III-severe restrictions & $\begin{array}{l}\text { Category IV-no formal } \\
\text { ICU structure }\end{array}$ \\
\hline $\begin{array}{l}\text { Typical setting (not including } \\
\text { private settings) }\end{array}$ & $\begin{array}{l}\text { High-income } \\
\text { countries }\end{array}$ & $\begin{array}{l}\text { Higher-middle income } \\
\text { countries }\end{array}$ & $\begin{array}{l}\text { Lower-middle and low-income } \\
\text { (major cities) countries }\end{array}$ & $\begin{array}{l}\text { Rural areas of } \\
\text { low-income countries }\end{array}$ \\
\hline Formal ICU structure/service & Yes & Yes & Partly & No \\
\hline $\begin{array}{l}\text { Availability of specifically } \\
\text { trained physicians and nurses }\end{array}$ & Widespread & Irregular & Rare & Unavailable \\
\hline $\begin{array}{l}\text { Availability of ICU equipment } \\
\text { (i.e. patient monitor, mechani- } \\
\text { cal ventilator, renal replace- } \\
\text { ment therapy) }\end{array}$ & Unrestricted & $\begin{array}{l}\text { Moderate restrictions (i.e. } \\
\text { irregular maintenance of } \\
\text { equipment, limited avail- } \\
\text { ability of advanced treatment } \\
\text { modalities such as RRT) }\end{array}$ & $\begin{array}{l}\text { Severe restrictions (i.e. basic monitor- } \\
\text { ing typically available, limited } \\
\text { number of mechanical ventila- } \\
\text { tors, widespread unavailability of } \\
\text { advanced treatment modalities } \\
\text { such as RRT) }\end{array}$ & Unavailable \\
\hline $\begin{array}{l}\text { Availability of ICU drugs and } \\
\text { disposable materials }\end{array}$ & Unrestricted & Minor restrictions & Moderate restrictions & Severe restrictions \\
\hline
\end{tabular}

The categories proposed here should not be seen as definite, but merely should serve as a starting point of future thinking

ICU intensive care unit, RRT renal replacement therapy 
Table 2 Availability of and recommendations for fluids in sepsis patients differ between resource-rich and resourcepoor settings

\begin{tabular}{|c|c|}
\hline Resource-rich setting & Resource-poor settings \\
\hline \multicolumn{2}{|l|}{ Availability } \\
\hline Fluids for intravenous infusion are widely available & $\begin{array}{l}\text { Fluids for intravenous infusion can be scarce, and the type of fluid chosen } \\
\text { could depend on its price (e.g., dextrose containing fluids, are cheaper and } \\
\text { thus more widely available) }\end{array}$ \\
\hline $\begin{array}{l}\text { Physicians and nurses, independent from each other, have free and } \\
\text { unlimited excess to fluids for intravenous infusion }\end{array}$ & $\begin{array}{l}\text { Decisions on start of intravenous infusion of fluids and the amounts given are } \\
\text { restricted to attending physicians }\end{array}$ \\
\hline \multicolumn{2}{|l|}{ Recommendations for fluids } \\
\hline Bacterial sepsis is the most common cause of sepsis & Non-bacterial sepsis and bacterial sepsis are equally present \\
\hline $\begin{array}{l}\text { Results from randomized controlled trials in patients with bacterial } \\
\text { sepsis favor liberal intravenous infusion of fluids }\end{array}$ & $\begin{array}{l}\text { Results from randomized controlled trials in patients with severe falciparum } \\
\text { malaria and in patients with Dengue Shock Syndrome suggest a more } \\
\text { restricted fluid therapy than recommended for bacterial sepsis to be better }\end{array}$ \\
\hline \multicolumn{2}{|l|}{ Potential consequences } \\
\hline $\begin{array}{l}\text { Free and unlimited excess to fluids for intravenous infusion may facili- } \\
\text { tate a'too liberal'fluid approach leading to 'overzealous' fluid resus- } \\
\text { citation, which is known to be associated with worse outcomes of } \\
\text { sepsis patients }\end{array}$ & $\begin{array}{l}\text { Shortage of fluids and a merely physician-driven fluid regimen may result } \\
\text { in inadequate resuscitation, either because of too low or too late given, or } \\
\text { wrong fluids infused, which may worsen outcome of bacterial as well as } \\
\text { non-bacterial sepsis patients }\end{array}$ \\
\hline
\end{tabular}

The categories proposed here should not be seen as definite, but merely should serve as a starting point of future thinking

ICU intensive care unit, RRT renal replacement therapy

Healthcare Systems' courses developed by the Chinese University of Hong Kong, Hong Kong, China, and Médecins Sans Frontières) are available. The theoretical knowledge of specialist doctors in developing countries is often impressive, but their ability to translate this into practical implementation can lag behind, which is an important scope for training. Training should not only be for ICU physicians, but also for nurses and other clinical personnel. It will be important that education on sepsis management does not focus only on ICU physicians, but includes medical schools, nursing schools and the training of other healthcare workers, as many sepsis patients in LMICs receive treatment outside an ICU. 'Train-the-trainer' models and fostering local champions for positive change are important to sustain improvements of care.

\section{Costs of care in sepsis}

\section{Expensive but likely cost-effective critical care}

The vast resources consumed by ICUs, up to a staggering $1 \%$ of total gross domestic product in the USA [51], demand that ICUs be subject to explicit economic costbenefit considerations [52]. The literature from highincome settings has indeed expanded over the past decade, demonstrating that many critical care interventions offer significant health returns, with costs per quality-adjusted life-year (QUALY) gained well below a threshold of US $\$ 50,000$, indicative of a cost-effective intervention in this context.

For countries in which more basic services are still relatively undeveloped it might be questioned whether investment in ICUs should take priority over the strengthening of lower tiers of the healthcare system [53]. Irrespective of these considerations, the reality is that in many growing economies ICUs are increasing in number [44], with virtually no evidence on the cost-effectiveness of their services.

\section{Costs of critical care amongst regions}

One approach is to consider the evidence from HICs, which have a much lower willingness to pay the abovementioned threshold. Applying a threshold of US $\$ 4000$ per QUALY gained [54] suggests that numerous ICU interventions, and those for sepsis in particular [55-61], are likely to be cost-effective in ICUs in LMICs (Table 3). For several reasons these cost-effectiveness ratios might be conservative in the context of LMICs. First, the cost of ICUs in these countries is much lower than in HICs. The two largest standardized multi-country reviews of critical care costs in high-income settings estimated the cost per ICU-day to range from US $\$ 850$ to US $\$ 3400$ in 2015 [62, 63], with labor being the dominant cost-driver (61 and 67\%, respectively). The proportional difference in labor costs between HICs and LMICs will be similar to or higher than that of their respective gross domestic product per capita [64]. This alone implies that the critical care costs in LMICs will be less than one-third that in HICs. Other costs, such as laboratory services ( $10 \%$ of total critical care cost [63]), are also likely to be far lower for similar reasons, as well as drug costs and cost-saving practices such as recycling of consumables [65]. In one of the few costing analyses of an ICU from a LMIC, the total 
Table 3 The cost-effectiveness of interventions for the management of severe sepsis

\begin{tabular}{|c|c|c|c|c|}
\hline First author/year & Cohorts (country) & Intervention & Conventional & Cost/QUALY (in 2015 US \$) \\
\hline Huang/2007 [57] & $\begin{array}{l}\text { Monte Carlo simulation of patients with } \\
\text { sepsis undergoing EGDT beginning } \\
\text { either in the ED or ICU (USA) }\end{array}$ & EGDT in ED or ICU & Standard care & $\$ 3506-8953$ \\
\hline Talmor/2008 [61] & $\begin{array}{l}\text { Prospective cohort study of patients } \\
\text { treated with an integrated sepsis proto- } \\
\text { col compared to controls (USA) }\end{array}$ & $\begin{array}{l}\text { Integrated sepsis } \\
\text { protocol }\end{array}$ & Standard care & $\$ 20,265(2015)$ \\
\hline Lehmann/2010 [60] & $\begin{array}{l}\text { Monte Carlo simulation of sepsis episodes } \\
\text { in ICU patients with use of PCR with cul- } \\
\text { tures to identify the causative organism } \\
\text { and initiate tailored antibiotic therapy } \\
\text { (EU) }\end{array}$ & PCR and cultures & $\begin{array}{l}\text { Traditional cultures } \\
\text { only }\end{array}$ & $\$ 3798$ \\
\hline Karlsson/2009 [59] & $\begin{array}{l}\text { Prospective cohort study of sepsis patients } \\
\text { admitted to the ICU who were followed } \\
\text { for } 2 \text { years (Finland) }\end{array}$ & $\begin{array}{l}\text { ICU care for severe } \\
\text { sepsis }\end{array}$ & Standard care & $\$ 2664$ \\
\hline Jones/2011 [58] & $\begin{array}{l}\text { Prospective before-after clinical trial to } \\
\text { establish the initiation of EGDT in the ED } \\
\text { prior to transfer to ICU for newly admit- } \\
\text { ted sepsis patients (USA) }\end{array}$ & EGDT for sepsis in ED & $\begin{array}{l}\text { Standard ED care for } \\
\text { sepsis }\end{array}$ & $\$ 6283(2015)$ \\
\hline Suarez/2011 [95] & $\begin{array}{l}\text { Prospective before-after clinical trial to } \\
\text { assess the impact of an educational pro- } \\
\text { gram on adherence to 'Surviving Sepsis } \\
\text { Campaign Guidelines' (Spain) }\end{array}$ & $\begin{array}{l}\text { Surviving sepsis } \\
\text { protocol for severe } \\
\text { sepsis }\end{array}$ & Standard care & $\$ 7810(2015)$ \\
\hline Assuncao/2014 [55] & $\begin{array}{l}\text { Prospective case-control analysis of } \\
\text { patients treated with EGDT vs. standard } \\
\text { care (Brazil) }\end{array}$ & EGDT & Standard care & Dominant \\
\hline Harrison/2015 [56] & $\begin{array}{l}\text { Markov model assessing cost-effective- } \\
\text { ness of PCT as a diagnostic tool for } \\
\text { bacterial infection in ICU patients (USA) }\end{array}$ & PCT & $\begin{array}{l}\text { Standard diagnostic } \\
\text { techniques }\end{array}$ & Dominant \\
\hline
\end{tabular}

ED Emergency department, EGDT early goal directed therapy, ICU intensive care unit, $P C R$ polymerase chain reaction, $P C T$ procalcitonin, QUALY quality-adjusted life-year

cost per ICU admission-day in India was estimated to be just over US \$200 [66], between approximately 5 and 20\% of that for HICs.

However, it is also important to consider the absolute financial outlay per intervention multiplied by the number of interventions, in particular in LMICs. Even in a wealthy country with a high threshold, tolerance to costs is very closely associated to the number of times the money for that intervention must be spent, especially if up-front costs are high. In other words, an intervention might appear to be cost-effective, but if it would have to be applied to a massive portion of the public, the costs would still be perceived as financially impossible. Consequently, there needs to be an effective system of triage in place to identify those patients who are most likely to benefit from these costly interventions; such a strategy is at times a challenge in LMICs.

Finally, we are uncertain whether applying a threshold of US \$4000 per QALY gained is one that could be promoted or generalized, as there is a large intra- and inter-region variation in resources. Country and ideally region-specific currency conversions/purchase power parity comparisons should be made.

\section{Benefit of critical care among regions}

The mean age of adult patients admitted to ICUs in HICs is consistently higher than those reported in LMIC. For example, in European ICUs the mean age of adult admissions is typically 55-66 years compared to the median age of 34 years in a Rwandan ICU [67], of 32 years in one of the few ICUs in Uganda [1], and of 37, 51 and 49 years in ICUs in Bangladesh, Nepal and India [68]. Although not specified for admission diagnosis, these data likely also reflect the younger age of sepsis patients and as such can be used as an argument to invest in better intensive care to save these young lives from a disease which is in principle treatable. Also, in LMICs where social security networks are usually lacking, the loss of an individual's economic activity has far more extensive economic consequences for the families involved.

By generalizing the evidence from $\mathrm{HICs}$ and considering the lower costs and higher potential gains there are strong indications that a wide range of critical care services are likely to be cost-effective in LMICs. Unfortunately, there is a dearth of evidence directly from these settings to confirm this notion. The only economic evaluation of an ICU in Bosnia-Herzegovina concluded that critical care was highly cost-effective in that specific 
setting [46]. A study in Brazil showed that the implementation of a sepsis management protocol was associated with an absolute reduction of $18 \%$ in mortality and with cost-savings [55].

\section{Impact of certain interventions among regions}

Despite these suggestions that a broad range of ICU services could be cost-effective in LMICs there is also reason for caution. First, some interventions are likely to have a much lower impact in poorly functioning environments than they might have in resource-rich settings. For example, monitoring for invasive infections in an ICU with poor basic infection control could result in more harm than benefit. For this reason it is imperative that basic standards of care are in place prior to the introduction of costly interventions whose effect might otherwise be compromised. Training programs to improve the general quality of care that require no costly interventions have been shown to have beneficial effects [68]. Second, while hypothetically cost-effectiveness should correspond with affordability, in LMICs where healthcare systems are often fragmented and divided between the private and public sector and an abundance of vertically funded health programs, this is often not the case. Therefore, it is imperative that only interventions with modest budgetary impacts are shortlisted for consideration and that from among these only those which have the greatest beneficial effects, with the lowest incremental costs, are selected for implementation. Some such low-cost approaches have been identified and should be prioritized for evaluation. Better surveillance systems for local etiologies of sepsis and antimicrobial susceptibility patterns have been recognized as a key requirement for improving the management of sepsis and critical care [4], and a modeling-based economic evaluation supports the notion that this strategy is likely to be highly cost-effective [69].

Likewise, the development and adaptation of LMICspecific risk prediction models have been shown to potentially outperform models widely used in highincome settings, such as the frequently used Acute Physiology and Chronic Health Evaluation (APACHE) score and the Simplified Acute Physiology Score (SAPS) [67], which might not even be feasible in many ICUs in LMICs. The same is true for scoring systems in children, and scoring systems that are context relevant should also be explored because the Pediatric Risk of Mortality (PRISM) score may underpredict mortality [70].

Critical care in general and a subset of specific interventions can be an efficient use of scarce resources in LMICs. However, despite the aforementioned lower costs, an ICU admission in, for example, India would most likely represent a catastrophic expenditure that would consume over one-half of the mean annual household income $[44,66]$ (see also Table 4). As such facilities expand in LMICs and inevitably consume increasing resources, it is imperative for health authorities to ensure that these offer affordable

Table 4 Critical care expenditure in Indian hospitals. In India critical care services are offered in four broad types of hospitals, with variable reimbursements. Variable reimbursements potentially leads to a great diversity in care of the critically ill, especially those who tend to have an extended ICU stay (i.e., longer than just a view days)

\begin{tabular}{|c|c|}
\hline Hospital types & Reimbursement policy \\
\hline 'Governmental hospitals' & $\begin{array}{l}\text { The ICU bed, ventilation, basic medications may be free of costs, but patient will need to spend out of pocket } \\
\text { for expensive medications like certain antibiotics, disposables and for the family to stay in a distinct place } \\
\text { (far) away from their homes. Often in a few days they will exhaust their meager finances after which their } \\
\text { care will be compromised. }\end{array}$ \\
\hline $\begin{array}{l}\text { 'Public charity trust hospitals' (including } \\
\text { hospitals of private medical colleges) }\end{array}$ & $\begin{array}{l}\text { 'Public charity trust hospitals' have a mandate to provide free treatment to patients below the poverty line. In } \\
\text { addition, these hospitals also offer concessional treatment under various governmental insurance schemes } \\
\text { for poor patients that, however, are mainly utilized for surgical patients and short stay patients like myocar- } \\
\text { dial infarction and stroke. The insurance offered for sepsis is very meager and cannot cover more than the } \\
\text { first few days in ICU. Patients thus will need to spend out of pocket for expensive medications like certain } \\
\text { antibiotics, disposables and for the family to stay in a distinct place (far) away from their homes. }\end{array}$ \\
\hline 'Private cooperative hospitals' & $\begin{array}{l}\text { 'Private cooperative hospitals' will treat affording patients either paying out of pocket or through some form } \\
\text { of insurance. Except for the rich and very rich in a week or two such patient will exhaust their finances and } \\
\text { will then either be transferred to 'governmental hospitals' or 'public charity trust hospitals'. These transfers } \\
\text { however are not easy given scarcity of beds.'Public charity trust hospitals' will generally have an admission } \\
\text { policy that will discourage patients that are deemed unsalvageable or may require some form of limitation } \\
\text { of therapy. 'Governmental hospitals' have to accept such patients but here the beds crunch is often more } \\
\text { severe. This leaves patient and care givers in a very difficult position and may lead to withdrawal of care or } \\
\text { discharge against medical advice. }\end{array}$ \\
\hline $\begin{array}{l}\text { 'Private nursing homes' (which are usu- } \\
\text { ally smaller then the other hospitals) }\end{array}$ & $\begin{array}{l}\text { 'Private nursing homes' may offer critical services for selected patients but this too follows a similar trajec- } \\
\text { tory as that of the 'private cooperative' hospitals, i.e., once patients' finances are exhausted they need to be } \\
\text { transferred. }\end{array}$ \\
\hline
\end{tabular}

Information provided by Shivakumar lyer

ICU intensive care unit 
and cost-effective services, while concurrently monitoring and continuing to seek opportunities to improve the quality of critical care and their efficiency at low cost. This approach was exemplified by the UK in the late 1990s, where a country-wide initiative to transform and modernize critical care was associated with a $10 \%$ reduction in mortality at lower cost increases than would otherwise be expected [71].

\section{Sepsis research in resource-limited settings}

\section{A yet largely untouched research agenda}

With only $1.7 \%$ of all biomedical research publications originating in low-income countries [72] and a likely even greater disparity in critical care [44], both the needs and the opportunities for critical care research are vast. Recent rigorous attempts to quantify the global burdens of sepsis, infection and respiratory failure confirm a profound lack of data on epidemiologic critical illness from low-income countries, with the only reliable data limited to single-center descriptions [67, 73-76]. The International Severe Acute Respiratory and Emerging Infection Consortium (ISARIC), the Global Intensive Care Working Group of the ESICM and the Mahidol Oxford Research Unit in Bangkok, Thailand, are three examples of groups working to create the infrastructure for global epidemiologic data on critical illness, for use both as baseline data at regular intervals but also in preparation for disease outbreaks [77].

Research on infectious diseases that lead to critical illness are perhaps the most successful areas of investigation thus far, with impressive scientific advancements in diseases such as malaria, tuberculosis and melioidosis [78-80]. Defining and testing quality metrics is an area prioritized in both critical care and global public health [81], but quality improvement in resourcelimited ICUs remains largely unexplored [44, 82]. The latter requires some ability to benchmark ICUs with severity of illness scores, also a nascent area of study [67]. Research into medical education models such as the Human Resources for Health program in Rwanda [83], decision-support tools like the Checklist for Early Recognition and Treatment of Acute IllNess (CERTAIN) [84] and Vital Signs Directed Therapy [85] could help in better defining how to optimize knowledge acquisition and application for providers in resourcelimited settings.

\section{Challenges with research in resource-restricted settings}

The realities of restriction in resources interact to create complex challenges to producing quality critical care research. Many short-term multi-site epidemiologic studies depend on individual sites to participate without funding for the perceived minimal data collection burden. However, staff at resource-constrained sites often cannot spare even the short-term investment required to participate, and 'standard' clinical data, such as arterial blood gas analyses and chest radiographs, are often not available in these sites [75, 77]. Likewise, multi-center clinical trials are significantly more expensive to perform in resource-limited settings since baseline clinical or analytic infrastructure of any sort cannot be assumed. Efforts to build resource capacity in research and to ensure fair authorship opportunities also mean that research has two resource-intensive and sometimes competing goals: that of developing local researchers without prior training and that of producing high-quality research. An unintended consequence of (appropriate) increasing involvement by local institutional review boards is that lack of staffing and experience may lead to unnecessary delays in research approvals. These resource barriers to collecting epidemiologic data are exacerbated by the fact that 'critical illness' is not a laboratory-defined condition, but rather one that is often defined by the expensive resources used to treat it $[28,86]$.

Ethical considerations are complex as well. All participants in resource-limited settings must be considered potentially 'vulnerable' populations due to extreme need and lack of health or research literacy. Deciding where equipoise exists for interventions proven to work in high-resource settings in settings of low resources is difficult. Asking the question, 'How do we do this better given limited resources?' uncomfortably raises the question 'How do we increase resources and to what extent are we obligated to do so?' Ethical considerations also include relationships between local and foreign researchers, the latter who often bring financial and experiential resources, leading to unequal power dynamics and potential for abuse [87]. Allowing lower standards for publication for research originating in low-resource settings has been considered in order to decrease some of the publication bias toward resource-rich settings; however, it is not at all clear that publishing poor-quality research that could impact clinical care is ethical or advisable.

\section{Suggestions for the future \\ Better definition of sepsis}

The latest sepsis definition [88], which refers to sepsis as life-threatening organ dysfunction caused by a dysregulated host response to infection, better reflects the fact that sepsis can complicate any serious acute infection. As pointed out earlier, direct damaging effects of the pathogen itself or of its products can sometimes be the main process. Consequently, research on sepsis treatment should not focus only on immunomodulating strategies in bacterial sepsis, but also on faster illumination of the pathogen and its products, an approach which could be 
particularly relevant in certain non-bacterial causes of sepsis, such as falciparum malaria, Cryptococcal infections and various viral infections.

Another unmet need is to validate the various definitions for sepsis in more varied populations, such as children in LMICs and adults in LMICs, and in areas where the causative pathogens of sepsis differ from those in Western countries where the present definitions have been developed.

\section{Better research infrastructures and planning}

Experience, resources and human power are critical for building evidence, and these are not routinely available in resource-poor settings. The global critical care community should help to build local clinical research capacities and contribute to obtaining adequate funding. Engagement of a variety of stakeholders, including local intensive care societies, healthcare authorities (e.g. Ministries of Health) and universities will be crucial in this respect [89]. There are large funding bodies, such as the Wellcome Trust, that support several efforts, but additional funds are clearly needed. The teaming up of researchers from established groups in HICs with local groups in resource-limited settings has proven to be a good model-provided equal and reciprocal relationships are guaranteed. Formulating essential topics for research will be important and could benefit from increased networking between critical care physicians from developing countries. This would also foster research networks needed to perform adequately powered clinical trials. Requirements for good-quality clinical research are not necessarily available in many developing countries, with often little infrastructure or human resources available for research. Hospitals and their doctors can be overburdened by their service delivery tasks, leaving little room for research. Offering a career path to clinical research physicians could free up manpower for improving evidence-based critical care. Priority settings and governance regarding financial resources for research and implementation projects will become extremely important. Also, local institutions, including ethical review boards, should help to create an enabling environment for research that benefits the local population, and not just promote the construction of unnecessary barriers, which is now at times the case.

\section{Obtaining relevant evidence, adapting guidelines}

Obtaining local intelligence on the most important causes of sepsis and the resistance patterns of the infecting microorganisms is crucial to guide local empirical antimicrobial treatment. Since microbiological capacity is often lacking in hospitals in LMICs, research collaborations could help to obtain this evidence from strategically located sentinel study sites.

We need additional recommendations for those interventions not yet covered in the published guidelines. Multi-center trials assessing clinical efficacy and effectiveness of new interventions and interventions known to be effective in resource-rich settings are sorely needed, given differences in epidemiologic and treatment contexts [44]. The Fluid Expansion as Supportive Therapy (FEAST) trial on fluid resuscitation in febrile African children with shock demonstrates that these trials are feasible and may yield unexpected results [90]. Networks of critical care researchers are increasingly being established in more resource-limited areas of the world, which could lead to additional studies of this kind [44]. Beyond these broad areas of research, specific subtypes deserve special attention in resource-limited settings. Social determinants of disease and barriers to care are of particular relevance to all research in resourcelimited settings, including intensive care [81]. While cost-effectiveness analyses are arguably important in all environments without infinite resources, their need is more acute in places with fewer resources to allocate [91]. Locally adapted prediction models can help ensure that interventions are targeted in a cost-effective manner.

Another important area for critical care research is on developing templates for expanding urban ICU capacity in rapidly growing cities [36]. Setting-specific guidance, rather than country-specific guidance, on how to build and equip an ICU is likely an additional and substantial area of research.

Finally, research on the process whereby scientific knowledge is translated into improved quality of care, i.e. 'global health delivery science', strikes at the immediate challenge in patient care in resource-poor settings, the fact that so much of what is known is not implemented effectively [81].

\section{Opportunities}

While the challenges are daunting, the opportunities are similarly impressive. Outbreaks like Ebola have increased the drive for intensive care research in resource-limited settings both by demonstrating how critical illness in these settings impacts people in resource-rich settings and by highlighting the need for improved critical care capacity in all areas of the world [92]. Interest in and funding for global health have increased steadily over the last few decades, such that career path and funding opportunities for researchers from HICs are better than ever before. Researchers from resource-limited settings now also have opportunities for high-quality training and mentorship through 
programs, such as those offered by the Wellcome Trust or United Kingdom Medical Research Council schemes and the American Thoracic Society's 'Methods in Epidemiologic, Clinical, and Operations Research' (MECOR) program [93].

An example of building a research structure is one from India, where the Indian Society of Critical Care Medicine initiated a 'cloud-based database' called 'Customized, Health in Intensive care, Trainable Research and Analysis (CHITRA) (http://www.isccm.org/chitra.aspx).

Finally, LMICs and HICs could mutually benefit from their research agendas; HICs also gain from more LMIC research. For example, considerations about direct pathogen effects in LMICs could, in turn, generate better critical thinking about sepsis, from which both HICs and LMICs gain. Similarly, technological innovation under resource constraints can yield gains for all. Critical care could be ripe for this at times called 'frugal innovation' or 'reverse innovation' concept [94]. Also, in our personal experience [68], nurses from HICs that have worked in LMICs, and even for a short time, are more cost-conscious than their colleagues.

\section{Conclusions}

Strategies to improve the quality of sepsis management in resource-poor settings require consideration of disease-specific and setting-specific factors and meticulous evaluation of the best way to adapt and deploy quality improvement initiatives. Critical care, including sepsis management, is expensive but likely cost-effective in LMICs, but we need to better understand what the true financial impact of critical care is, both at a macro- and micro-economy level. Sepsis management in resourcelimited settings is a largely unexplored frontier with a clear mandate and exciting opportunities for impact.

\footnotetext{
Author details

${ }^{1}$ Mahidol University, Bangkok, Thailand. ${ }^{2}$ Department of Intensive Care, Academic Medical Center and University of Amsterdam, Meibergdreef 9, 1105 AZ Amsterdam, The Netherlands. ${ }^{3}$ University College of London Hospital, London, UK. ${ }^{4}$ Sunnybrook Health Sciences Centre and University of Toronto, Toronto, ON, Canada. ${ }^{5}$ Bharati Vidyapeeth Deemed University Medical College, Pune, India. ${ }^{6}$ Mulago National Referral Hospital, Kampala, Uganda. ${ }^{7}$ University of Maryland School of Medicine, Baltimore, MD, USA. ${ }^{8}$ Beth Israel Deaconess Medical Center and Harvard Medical School, Boston, MA, USA. ${ }^{9}$ University of Pittsburgh, Pittsburgh, PA, USA. ${ }^{10}$ Hospital Sirio-Libanes, Saõ Paulo, Brazil. ${ }^{11}$ Karolinska Institute, Stockholm, Sweden. ${ }^{12}$ California Pacific Medical Center, San Francisco, CA, USA. ${ }^{13}$ Mayo Clinic, Jacksonville, FL, USA. ${ }^{14}$ Stony Brook University Medical Center, Stony Brook, NY, USA. ${ }^{15}$ University of Washington, Seattle, WA, USA. ${ }^{16}$ British Columbia Children's Hospital, Vancouver, Canada.

${ }^{17}$ All India Institute of Medical Science, Delhi, India. ${ }^{18}$ St. James's University Hospital, Dublin, Ireland. ${ }^{19}$ Mongolian National University of Medical Sciences, Ulaanbaatar, Mongolia. ${ }^{20}$ Aga Khan University Hospital, Nairobi, Kenya. ${ }^{21}$ Johannesburg Hospital and University of the Witwatersrand, Johannesburg South Africa. ${ }^{22}$ Ispat General Hospital, Sundargarh, Rourkela, Odisha, India.

${ }^{23}$ Seattle Children's Hospital and University of Washington, Seattle, WA, USA.

${ }^{24}$ Medical Intensive Care Unit, Hospital Israelita Albert Einstein, Sao Paulo, Brazil.

${ }^{25}$ Oxford University Clinical Research Unit, Hospital for Tropical Diseases, District
}

5, Ho Chi Minh City, Vietnam. ${ }^{26}$ Trung Vuong Hospital, Ho Chi Minh City, Vietnam. ${ }^{27}$ National University Hospital, Singapore, Singapore. ${ }^{28}$ Addenbrooke's Hospital, Cambridge University Hospitals NHS Foundation Trust, Cambridge, UK. ${ }^{29}$ Nova Medical School, CEDOC, New University of Lisbon and Hospital de Sao Francisco Xavier, Centro Hospitalar de Lisboa Ocidental, Lisbon, Portugal. ${ }^{30}$ Appolo Hospitals, Chennai, India. ${ }^{31}$ Mzuzu Central Hospital, Mzuzu, Malawi.

${ }^{32}$ Nuffield Department of Medicine, Centre for Tropical Medicine and Global Health, University of Oxford, Oxford, UK.

Received: 25 November 2016 Accepted: 27 February 2017

Published online: 27 March 2017

\section{References}

1. Kwizera A, Festic E, Dunser MW (2016) What's new in sepsis recognition in resource-limited settings? Intensive Care Med 42:2030

2. Musa N, Murthy S, Kissoon N (2016) Pediatric sepsis and septic shock management in resource-limited settings. Intensive Care Med 42(12):2037-2039

3. Serpa Neto A, Schultz MJ, Festic E (2016) Ventilatory support of patients with sepsis or septic shock in resource-limited settings. Intensive Care Med 42:100-103

4. Thwaites $C L$, Lundeg $G$, Dondorp AM, sepsis in resource-limited settingsexpert consensus recommendations group of the European Society of Intensive Care M, the Mahidol-Oxford Research Unit in BangkokT (2016) Recommendations for infection management in patients with sepsis and septic shock in resource-limited settings. Intensive Care Med 2(12):2040-2042

5. Martin GS, Mannino DM, Eaton S, Moss M (2003) The epidemiology of sepsis in the United States from 1979 through 2000. N Engl J Med 348:1546-1554

6. Vincent JL, Sakr Y, Sprung CL, Ranieri VM, Reinhart K, Gerlach H, Moreno R, Carlet J, Le Gall JR, Payen D, Sepsis Occurrence in Acutely III Patients I (2006) Sepsis in European intensive care units: results of the SOAP study. Crit Care Med 34:344-353

7. Phua J, Koh Y, Du B, Tang YQ, Divatia JV, Tan CC, Gomersall CD, Faruq MO, Shrestha BR, Gia Binh N, Arabi YM, Salahuddin N, Wahyuprajitno B, Tu ML, Wahab AY, Hameed AA, Nishimura M, Procyshyn M, Chan YH, Group MS (2011) Management of severe sepsis in patients admitted to Asian intensive care units: prospective cohort study. BMJ 342:d3245

8. Murthy S, Leligdowicz A, Adhikari NK (2015) Intensive care unit capacity in low-income countries: a systematic review. PLoS One 10:e0116949

9. Cheng AC, West TE, Limmathurotsakul D, Peacock SJ (2008) Strategies to reduce mortality from bacterial sepsis in adults in developing countries. PLoS Med 5:e175

10. GBD 2013 Mortality and Causes of Death Collaborators (2015) Global, regional, and national age-sex specific all-cause and cause-specific mortality for 240 causes of death, 1990-2013: a systematic analysis for the Global Burden of Disease Study 2013. Lancet 385:117-171

11. Global Burden of Disease Study 2013 Collaborators (2015) Global, regional, and national incidence, prevalence, and years lived with disability for 301 acute and chronic diseases and injuries in 188 countries, 1990-2013: a systematic analysis for the Global Burden of Disease Study 2013. Lancet 386:743-800

12. GBD 2015 Mortality and Causes of Death Collaborators (2016) Global, regional, and national life expectancy, all-cause mortality, and causespecific mortality for 249 causes of death, 1980-2015: a systematic analysis for the Global Burden of Disease Study 2015. Lancet 388:1459-1544

13. Rosenthal VD, Bijie H, Maki DG, Mehta Y, Apisarnthanarak A, Medeiros EA, Leblebicioglu H, Fisher D, Alvarez-Moreno C, Khader IA, Martinez MDRG, Cuellar LE, Navoa-Ng JA, Abouqal R, Guanche Garcell H, Mitrev Z, Pirez Garcia MC, Hamdi A, Duenas L, Cancel E, Gurskis V, Rasslan O, Ahmed A, Kanj SS, Ugalde OC, Mapp T, Raka L, Yuet Meng C, le Thu TA, Ghazal S, Gikas A, Narvaez LP, Mejia N, Hadjieva N, Gamar Elanbya MO, Guzman Siritt ME, Jayatilleke K, Members I (2012) International Nosocomial Infection Control Consortium (INICC) report, data summary of 36 countries, for 2004-2009. Am J Infect Control 40:396-407 
14. Frikha N, Mebazaa M, Mnif L, El Euch N, Abassi M, Ben Ammar MS (2005) Septic shock in a Tunisian intensive care unit: mortality and predictive factors. 100 cases. Tunis Med 83:320-325

15. Jacob ST, Moore CC, Banura P, Pinkerton R, Meya D, Opendi P, Reynolds SJ, Kenya-Mugisha N, Mayanja-Kizza H, Scheld WM, Promoting ResourceLimited Interventions for Sepsis Management in Uganda Study G (2009) Severe sepsis in two Ugandan hospitals: a prospective observational study of management and outcomes in a predominantly HIV-1 infected population. PLoS One 4:e7782

16. Siddiqui S (2007) Not "surviving sepsis" in the developing countries. J Indian Med Assoc 105:221

17. Dunser MW, Bataar O, Tsenddorj G, Lundeg G, Torgersen C, Romand JA, Hasibeder WR, Helfen Beruhrt Study T (2008) Differences in critical care practice between an industrialized and a developing country. Wien Klin Wochenschr 120:600-607

18. Vernet G, Mary C, Altmann DM, Doumbo O, Morpeth S, Bhutta ZA, Klugman KP (2014) Surveillance for antimicrobial drug resistance in underresourced countries. Emerg Infect Dis 20:434-441

19. Laxminarayan R, Matsoso P, Pant S, Brower C, Rottingen JA, Klugman K, Davies S (2016) Access to effective antimicrobials: a worldwide challenge. Lancet 387:168-175

20. Bone RC, Balk RA, Cerra FB, Dellinger RP, Fein AM, Knaus WA, Schein RM, Sibbald WJ (1992) Definitions for sepsis and organ failure and guidelines for the use of innovative therapies in sepsis. The ACCP/SCCM Consensus Conference Committee. American College of Chest Physicians/Society of Critical Care Medicine. Chest 101:1644-1655

21. Levy MM, Fink MP, Marshall JC, Abraham E, Angus D, Cook D, Cohen J, Opal SM, Vincent JL, Ramsay G, International Sepsis Definitions C (2003) 2001 SCCM/ESICM/ACCP/ATS/SIS International Sepsis Definitions Conference. Intensive Care Med 29:530-538

22. Kissoon N, Daniels R, van der Poll T, Finfer S, Reinhart K (2016) Sepsis-the final common pathway to death from multiple organ failure in infection. Crit Care Med 44:e446

23. Auma MA, Siedner MJ, Nyehangane $D$, Nalusaji A, Nakaye M, MwangaAmumpaire J, Muhindo R, Wilson LA, Boum Y 2nd, Moore CC (2013) Malaria is an uncommon cause of adult sepsis in south-western Uganda. Malar J 12:146

24. White NJ, Pukrittayakamee S, Hien TT, Faiz MA, Mokuolu OA, Dondorp AM (2014) Malaria. Lancet 383:723-735

25. White NJ, Turner GD, Day NP, Dondorp AM (2013) Lethal malaria: Marchiafava and Bignami were right. J Infect Dis 208:192-198

26. Chen Y, Maguire T, Hileman RE, Fromm JR, Esko JD, Linhardt RJ, Marks RM (1997) Dengue virus infectivity depends on envelope protein binding to target cell heparan sulfate. Nat Med 3:866-871

27. Avirutnan P, Zhang L, Punyadee N, Manuyakorn A, Puttikhunt C, Kasinrerk W, Malasit P, Atkinson JP, Diamond MS (2007) Secreted NS1 of denque virus attaches to the surface of cells via interactions with heparan sulfate and chondroitin sulfate E. PLoS Pathog 3:e183

28. Adhikari NK, Fowler RA, Bhagwanjee S, Rubenfeld GD (2010) Critical care and the global burden of critical illness in adults. Lancet 376:1339-1346

29. Haniffa R, De Silva AP, Iddagoda S, Batawalage H, De Silva ST, Mahipala PG, Dondorp A, de Keizer N, Jayasinghe S (2014) A cross-sectional survey of critical care services in Sri Lanka: a lower middle-income country. J Crit Care 29:764-768

30. Mendsaikhan N, Begzjav T, Lundeg G, Brunauer A, Dunser MW (2016) A nationwide census of ICU capacity and admissions in Mongolia. PLoS One 11:e0160921

31. Jochberger S, Ismailova F, Lederer W, Mayr VD, Luckner G, Wenzel V, Ulmer H, Hasibeder WR, Dunser MW, Helfen Beruhrt Study T (2008) Anesthesia and its allied disciplines in the developing world: a nationwide survey of the Republic of Zambia. Anesth Analg 106:942-948 (Table of contents)

32. Kwizera A, Dunser M, Nakibuuka J (2012) National intensive care unit bed capacity and ICU patient characteristics in a low income country. BMC Res Notes 5:475

33. Campos-Mino S, Sasbon JS, von Dessauer B (2012) Pediatric intensive care in Latin America. Med Intensiva 36:3-10

34. Kissoon N (2016) Sepsis care differences unlike beauty are not skin deep. Pediatr Crit Care Med 17:568-569

35. Divatia JV, Amin PR, Ramakrishnan N, Kapadia FN, Todi S, Sahu S, Govil D, Chawla R, Kulkarni AP, Samavedam S, Jani CK, Rungta N, Samaddar DP,
Mehta S, Venkataraman R, Hegde A, Bande BD, Dhanuka S, Singh V, Tewari R, Zirpe K, Sathe P, INDICAPS Study Investigators (2016) Intensive care in India: the indian intensive care case mix and practice patterns study. Indian J Crit Care Med 20:216-225

36. Austin S, Murthy S, Wunsch H, Adhikari NK, Karir V, Rowan K, Jacob ST, Salluh J, Bozza FA, Du B, An Y, Lee B, Wu F, Nguyen YL, Oppong C, Venkataraman R, Velayutham V, Duenas C, Angus DC, International Forum of Acute Care (2014) Access to urban acute care services in high-vs. middle-income countries: an analysis of seven cities. Intensive Care Med 40:342-352

37. Marshall JC, Bosco L, Adhikari NK, Connolly B, Diaz JV, Dorman T, Fowler RA, Meyfroidt G, Nakagawa S, Pelosi P, Vincent JL, Vollman K, Zimmerman $J$ (2017) What is an intensive care unit? A report of the task force of the World Federation of Societies of Intensive and Critical Care Medicine. J Crit Care 37:270-276

38. Rhodes A, Ferdinande P, Flaatten H, Guidet B, Metnitz PG, Moreno RP (2012) The variability of critical care bed numbers in Europe. Intensive Care Med 38:1647-1653

39. Baelani I, Jochberger S, Laimer T, Otieno D, Kabutu J, Wilson I, Baker T, Dunser MW (2011) Availability of critical care resources to treat patients with severe sepsis or septic shock in Africa: a self-reported, continentwide survey of anaesthesia providers. Crit Care 15:R10

40. Baker T, Lugazia E, Eriksen J, Mwafongo V, Irestedt L, Konrad D (2013) Emergency and critical care services in Tanzania: a survey of ten hospitals. BMC Health Serv Res 13:140

41. Bataar O, Lundeg G, Tsenddorj G, Jochberger S, Grander W, Baelani I, Wilson I, Baker T, Dunser MW, Helfen Beruhrt Study T (2010) Nationwide survey on resource availability for implementing current sepsis guidelines in Mongolia. Bull World Health Organ 88:839-846

42. Hsia RY, Mbembati NA, Macfarlane S, Kruk ME (2012) Access to emergency and surgical care in sub-Saharan Africa: the infrastructure gap. Health Policy Plan 27:234-244

43. Arabi YM, Phua J, Koh Y, Du B, Faruq MO, Nishimura M, Fang WF, Gomersall C, Al Rahma HN, Tamim H, Al-Dorzi HM, Al-Hameed FM, Adhikari NK, Sadat M, Asian Critical Care Clinical Trials G (2016) Structure, organization, and delivery of critical care in Asian ICUs. Crit Care Med 44:e940-e948

44. Dondorp AM, lyer SS, Schultz MJ (2016) Critical care in resource-restricted settings. JAMA 315:753-754

45. Mendsaikhan N, Begzjav T, Lundeg G, Dünser MW (2016) Potentially preventable deaths by intensive care medicine in Mongolian hospitals. Crit Care Res Pract 2016:8624035. Available at: http://dx.doi. org/10.1155/2016/8624035

46. Cubro H, Somun-Kapetanovic R, Thiery G, Talmor D, Gajic O (2016) Cost effectiveness of intensive care in a low resource setting: a prospective cohort of medical critically ill patients. World J Crit Care Med 5:150-164

47. Phua J, Joynt GM, Nishimura M, Deng Y, Myatra SN, Chan YH, Binh NG, Tan CC, Faruq MO, Arabi YM, Wahjuprajitno B, Liu SF, Hashemian SM, Kashif W, Staworn D, Palo JE, Koh Y, Investigators AS, Asian Critical Care Clinical Trials G (2016) Withholding and withdrawal of life-sustaining treatments in low-middle-income versus high-income Asian countries and regions. Intensive Care Med 42:1118-1127

48. Kissoon N (2016) Healthcare costs to poor families: an agonising burden. Indian J Pediatr 83:1063-1064

49. Dunser MW, Festic E, Dondorp A, Kissoon N, Ganbat T, Kwizera A, Haniffa R, Baker T, Schultz MJ, Global Intensive Care Working Group of European Society of Intensive Care M (2012) Recommendations for sepsis management in resource-limited settings. Intensive Care Med 38:557-574

50. Dellinger RP, Levy MM, Rhodes A, Annane D, Gerlach H, Opal SM, Sevransky JE, Sprung CL, Douglas IS, Jaeschke R, Osborn TM, Nunnally ME, Townsend SR, Reinhart K, Kleinpell RM, Angus DC, Deutschman CS, Machado FR, Rubenfeld GD, Webb SA, Beale RJ, Vincent JL, Moreno R, Surviving Sepsis Campaign Guidelines Committee including The Pediatric Subgroup (2013) Surviving sepsis campaign: international guidelines for management of severe sepsis and septic shock: 2012. Crit Care Med 41:580-637

51. Halpern NA, Pastores SM, Greenstein RJ (2004) Critical care medicine in the United States 1985-2000: an analysis of bed numbers, use, and costs. Crit Care Med 32:1254-1259

52. Pinsky MR (2002) Understanding costs and cost-effectiveness in critical care: report from the second American Thoracic Society workshop on outcomes research. Am J Respir Crit Care Med 165:540-550 
53. Shann F (2011) Role of intensive care in countries with a high child mortality rate. Pediatr Crit Care Med 12:114-115

54. Approximating the GNI per capita used to differentiate between a lowermiddle and upper-middle income country by the World Bank. World Bank, New York. https://datahelpdesk.worldbank.org/knowledgebase/ articles/906519-world-bank-country-and-lending-groups. Accessed 14 Mar 2017

55. Assuncao MS, Teich V, Shiramizo SC, Araujo DV, Carrera RM, Serpa Neto A, Silva E (2014) The cost-effectiveness ratio of a managed protocol for severe sepsis. J Crit Care 29(692):e691-e696

56. Harrison M, Collins CD (2015) Is procalcitonin-guided antimicrobial use cost-effective in adult patients with suspected bacterial infection and sepsis? Infect Control Hosp Epidemiol 36:265-272

57. Huang DT, Clermont G, Dremsizov TT, Angus DC, Pro Cl (2007) Implementation of early goal-directed therapy for severe sepsis and septic shock: a decision analysis. Crit Care Med 35:2090-2100

58. Jones AE, Troyer JL, Kline JA (2011) Cost-effectiveness of an emergency department-based early sepsis resuscitation protocol. Crit Care Med 39:1306-1312

59. Karlsson S, Ruokonen E, Varpula T, Ala-Kokko TI, Pettila V, Finnsepsis Study G (2009) Long-term outcome and quality-adjusted life years after severe sepsis. Crit Care Med 37:1268-1274

60. Lehmann LE, Herpichboehm B, Kost GJ, Kollef MH, Stuber F (2010) Cost and mortality prediction using polymerase chain reaction pathogen detection in sepsis: evidence from three observational trials. Crit Care 14:R186

61. Talmor D, Greenberg D, Howell MD, Lisbon A, Novack V, Shapiro N (2008) The costs and cost-effectiveness of an integrated sepsis treatment protocol. Crit Care Med 36:1168-1174

62. Negrini D, Sheppard L, Mills GH, Jacobs P, Rapoport J, Bourne RS, Guidet B, Csomos A, Prien T, Anderson G, Edbrooke DL (2006) International programme for resource use in critical care (IPOC) - a methodology and initial results of cost and provision in four European countries. Acta Anaesthesiol Scand 50:72-79

63. Tan SS, Bakker J, Hoogendoorn ME, Kapila A, Martin J, Pezzi A, Pittoni G, Spronk PE, Welte R, Hakkaart-van Roijen L (2012) Direct cost analysis of intensive care unit stay in four European countries: applying a standardized costing methodology. Value Health 15:81-86

64. Dräger S, Dal Poz MR, Evans DB (2006) Health workers wages: an overview from selected countries. World Health Organization, Geneva

65. Parikh CR, Karnad DR (1999) Quality, cost, and outcome of intensive care in a public hospital in Bombay, India. Crit Care Med 27:1754-1759

66. Kulkarni AP, Divatia JV (2013) A prospective audit of costs of intensive care in cancer patients in India. Indian J Crit Care Med 17:292-297

67. Riviello ED, Kiviri W, Fowler RA, Mueller A, Novack V, Banner-Goodspeed VM, Weinkauf JL, Talmor DS, Twagirumugabe T (2016) Predicting mortality in low-income country ICUs: the Rwanda Mortality Probability Model (R-MPM). PLoS One 11:e0155858

68. Haniffa R, Lubell Y, Cooper BS, Mohanty S, Shamsul A, Karki A, Pattnaik R, Maswood A, Pangeni R, Schultz MJ, Dondorp AM, Impact of a structured ICU training programme in resource-limited settings in Asia. PLoS One. doi:10.1371/journal.pone. 0173483

69. Penno EC, Baird SJ, Crump JA (2015) Cost-effectiveness of surveillance for bloodstream infections for sepsis management in low-resource settings. Am J Trop Med Hyg 93:850-860

70. Thukral A, Lodha R, Irshad M, Arora NK (2006) Performance of pediatric risk of mortality (PRISM), Pediatric index of mortality (PIM), and PIM2 in a pediatric intensive care unit in a developing country. Pediatr Crit Care Med 7:356-361

71. Hutchings A, Durand MA, Grieve R, Harrison D, Rowan K, Green J, Cairns J, Black N (2009) Evaluation of modernisation of adult critical care services in England: time series and cost effectiveness analysis. BMJ 339:b4353

72. Rahman M, Fukui T (2003) Biomedical publication—global profile and trend. Pub Health 117:274-280

73. Bellani G, Laffey JG, Pham T, Fan E, Brochard L, Esteban A, Gattinoni L, van Haren F, Larsson A, McAuley DF, Ranieri M, Rubenfeld G, Thompson BT, Wrigge H, Slutsky AS, Pesenti A, Investigators LS, Group ET (2016) Epidemiology, patterns of care, and mortality for patients with acute respiratory distress syndrome in intensive care units in 50 countries. JAMA 315:788-800

74. Fleischmann C, Scherag A, Adhikari NK, Hartog CS, Tsaganos T, Schlattmann P, Angus DC, Reinhart K, International Forum of Acute Care
T (2016) Assessment of global incidence and mortality of hospitaltreated sepsis. current estimates and limitations. Am J Respir Crit Care Med 193:259-272

75. Vincent JL, Marshall JC, Namendys-Silva SA, Francois B, Martin-Loeches I, Lipman J, Reinhart K, Antonelli M, Pickkers P, Njimi H, Jimenez E, Sakr $Y$, Investigators I (2014) Assessment of the worldwide burden of critical illness: the intensive care over nations (ICON) audit. Lancet Respir Med 2:380-386

76. Kang KT, Chandler HK, Espinosa V, Kissoon N (2014) Systems for paediatric sepsis: a global survey. West Indian Med J 63:703-710

77. International Severe Acute Respiratory and Emerging Infection Consortium (2016). https://isaric.tghn.org/about/. Accessed 14 Mar 2017

78. Ashley EA, Dhorda M, Fairhurst RM, Amaratunga C, Lim P, Suon S, Sreng S, Anderson JM, Mao S, Sam B, Sopha C, Chuor CM, Nguon C, Sovannaroth S, Pukrittayakamee S, Jittamala P, Chotivanich K, Chutasmit K, Suchatsoonthorn C, Runcharoen R, Hien TT, Thuy-Nhien NT, Thanh NV, Phu NH, Htut Y, Han KT, Aye KH, Mokuolu OA, Olaosebikan RR, Folaranmi OO, Mayxay M, Khanthavong M, Hongvanthong B, Newton PN, Onyamboko MA, Fanello Cl, Tshefu AK, Mishra N, Valecha N, Phyo AP, Nosten F, Yi P, Tripura R, Borrmann S, Bashraheil M, Peshu J, Faiz MA, Ghose A, Hossain MA, Samad R, Rahman MR, Hasan MM, Islam A, Miotto O, Amato R, Maclnnis B, Stalker J, Kwiatkowski DP, Bozdech Z, Jeeyapant A, Cheah PY, Sakulthaew T, Chalk J, Intharabut B, Silamut K, Lee SJ, Vihokhern B, Kunasol C, Imwong M, Tarning J, Taylor WJ, Yeung S, Woodrow CJ, Flegg JA, Das D, Smith J, Venkatesan M, Plowe CV, Stepniewska K, Guerin PJ, Dondorp AM, Day NP, White NJ, Tracking Resistance to Artemisinin C (2014) Spread of artemisinin resistance in Plasmodium falciparum malaria. N Engl J Med 371:411-423

79. Chantratita N, Tandhavanant S, Myers ND, Seal S, Arayawichanont A, Kliangsa-Ad A, Hittle LE, Ernst RK, Emond MJ, Wurfel MM, Day NP, Peacock SJ, West TE (2013) Survey of innate immune responses to Burkholderia pseudomallei in human blood identifies a central role for lipopolysaccharide. PLoS One 8:e81617

80. Desjardins CA, Cohen KA, Munsamy V, Abeel T, Maharaj K, Walker BJ, Shea TP, Almeida DV, Manson AL, Salazar A, Padayatchi N, O'Donnell MR, Mlisana KP, Wortman J, Birren BW, Grosset J, Earl AM, Pym AS (2016) Genomic and functional analyses of Mycobacterium tuberculosis strains implicate ald in D-cycloserine resistance. Nat Genet 48:544-551

81. Kim JY, Farmer P, Porter ME (2013) Redefining global health-care delivery. Lancet 382:1060-1069

82. Scott KW, Jha AK (2014) Putting quality on the global health agenda. N Engl J Med 371:3-5

83. Binagwaho A, Kyamanywa P, Farmer PE, Nuthulaganti T, Umubyeyi B, Nyemazi JP, Mugeni SD, Asiimwe A, Ndagijimana U, Lamphere McPherson H, Ngirabega Jde D, Sliney A, Uwayezu A, Rusanganwa V, Wagner CM, Nutt CT, Eldon-Edington M, Cancedda C, Magaziner IC, Goosby E (2013) The human resources for health program in Rwanda-new partnership. N Engl J Med 369:2054-2059

84. Vukoja M, Kashyap R, Gavrilovic S, Dong Y, Kilickaya O, Gajic O (2015) Checklist for early recognition and treatment of acute illness: international collaboration to improve critical care practice. World J Crit Care Med 4:55-61

85. Baker T, Schell CO, Lugazia E, Blixt J, Mulungu M, Castegren M, Eriksen J, Konrad D (2015) Vital signs directed therapy: improving care in an intensive care unit in a low-income country. PLoS One 10:e0144801

86. Riviello ED, Kiviri W, Twagirumugabe T, Mueller A, Banner-Goodspeed VM, Officer L, Novack V, Mutumwinka M, Talmor DS, Fowler RA (2016) Hospital incidence and outcomes of the acute respiratory distress syndrome using the kigali modification of the Berlin definition. Am J Respir Crit Care Med 193:52-59

87. Chu KM, Jayaraman S, Kyamanywa P, Ntakiyiruta G (2014) Building research capacity in Africa: equity and global health collaborations. PLoS Med 11:e1001612

88. Singer M, Deutschman CS, Seymour CW, Shankar-Hari M, Annane D, Bauer M, Bellomo R, Bernard GR, Chiche JD, Coopersmith CM, Hotchkiss RS, Levy MM, Marshall JC, Martin GS, Opal SM, Rubenfeld GD, van der Poll T, Vincent JL, Angus DC (2016) The third international consensus definitions for sepsis and septic shock (sepsis-3). JAMA 315:801-810

89. Arabi YM, Schultz MJ, Salluh JI (2016) Intensive Care Medicine in 2050: global perspectives. Intensive Care Med. 1-5. doi:10.1007/ s00134-016-4631-x 
90. Maitland K, Kiguli S, Opoka RO, Engoru C, Olupot-Olupot P, Akech SO, Nyeko R, Mtove G, Reyburn H, Lang T, Brent B, Evans JA, Tibenderana JK, Crawley J, Russell EC, Levin M, Babiker AG, Gibb DM, Group FT (2011) Mortality after fluid bolus in African children with severe infection. N Engl J Med 364:2483-2495

91. Riviello ED, Letchford S, Cook EF, Waxman AB, Gaziano T (2015) Improving decision making for massive transfusions in a resource poor setting: a preliminary study in Kenya. PLoS One 10:e0127987

92. Leligdowicz A, Fischer WA 2nd, Uyeki TM, Fletcher TE, Adhikari NK, Portella G, Lamontagne F, Clement C, Jacob ST, Rubinson L, Vanderschuren A, Hajek J, Murthy S, Ferri M, Crozier I, Ibrahima E, Lamah MC, Schieffelin JS, Brett-Major D, Bausch DG, Shindo N, Chan AK, O'Dempsey T, Mishra S, Jacobs M, Dickson S, Lyon GM 3rd, Fowler RA (2016) Ebola virus disease and critical illness. Crit Care 20:217
93. Buist AS, Parry V (2013) The American Thoracic Society methods in epidemiologic, clinical, and operations research program. A research capacitybuilding program in low- and middle-income countries. Ann Am Thorac Soc 10:281-289

94. Howitt P, Darzi A, Yang GZ, Ashrafian H, Atun R, Barlow J, Blakemore A, Bull AM, Car J, Conteh L, Cooke GS, Ford N, Gregson SA, Kerr K, King D, Kulendran M, Malkin RA, Majeed A, Matlin S, Merrifield R, Penfold HA, Reid SD, Smith PC, Stevens MM, Templeton MR, Vincent C, Wilson E (2012) Technologies for global health. Lancet 380:507-535

95. Suarez D, Ferrer R, Artigas A, Azkarate I, Garnacho-Montero J, Goma G, Levy MM, Ruiz JC, Edusepsis Study G (2011) Cost-effectiveness of the Surviving Sepsis Campaign protocol for severe sepsis: a prospective nation-wide study in Spain. Intensive Care Med 37:444-452 